\title{
PENGARUH RETURN ON ASSET, RETURN ON EQUITY, ECONOMIC VALUE ADDED DAN NET PROFIT MARGIN TERHADAP HARGA SAHAM DI BURSA EFEK INDONESIA (STUDI PADA PERUSAHAAN REAL ESTATE \& PROPERTY) PERIODE 2012-2016
}

\author{
Irma Dwi Puspita Dewi \\ Fakultas Ekonomi dan Bisnis \\ Universitas Islam Syekh-Yusuf Tangerang \\ dpuspitadewi@unis.ac.id \\ DOI: https://doi.org/10.33592/jeb.v26i1.620
}

\begin{abstract}
The study entitled "The Influence of Return on Asset, Return on Equity, Economic Value Added and Net Profit Margin on Stock Prices in the Indonesia Stock Exchange" this study discusses the influence given by Return on Asset, Return On Equity, Economic Value Added and Net Profit Margin Against Share Prices The purpose of this study are: (1) to determine partially whether ROA, ROE, EVA and NPM have a significant influence on the stock price of real estate and property companies for the period 2012-2016. (2) to determine simultaneously whether ROA, ROE, EVA and NPM had a significant influence on the stock price of real estate and property companies for the period 2012-2016, the number of samples was taken using the purposive sampling method obtained by 25 companies included in the criteria. Data analysis uses multiple linear regression analysis techniques with the assumption of auto correlation normality classics, multicollinearity and heteroskedacity. The conclusion of this study is based on simultaneous test (test f) and partial test ( $t$ test) with a significance of 5\%. Based on the analysis, it was concluded that partially the effect was not significant and simultaneously Return on Assets, Returns on Equity, Economic Value Added and Net Profit Margin had a significant effect of 0.002 on the stock price with the determination coefficient of $0.566 \%$. This shows that $0.566 \%$ of the stock price is explained by five independent variables and then explained by other variables not included in this study.
\end{abstract}

Keywords: Return on Asset, Return on Equity, Economic Value Added and Net Profit Price Margin

\begin{abstract}
ABSTRAK
Penelitian berjudul "Pengaruh Return On Asset, Return On Equity, Economic Value Added Dan Net Profit Margin Terhadap Harga Saham Di Bursa Efek Indonesia" penelitian ini membahas pengaruh yang diberikan oleh Return On Asset, Return On Equity, Economic Value Added Dan Net Profit Margin Terhadap Harga Saham tujuan penelitian ini adalah : (1) untuk menentukan secara parsial apakah ROA, ROE, EVA dan NPM memiliki pengaruh signifikan terhadap harga saham perusahaan real estate and property periode 2012 - 2016. (2) untuk menentukan secara bersamaan apakah ROA, ROE, EVA dan NPM memiliki pengaruh signifikan terhadap harga saham perusahaan real estate and property periode 2012 - 2016 jumlah sempel adalah diambil
\end{abstract}


dengan menggunakan metode purposive sampling yang di peroleh 25 perusahaan yang termasuk kedalam kriteria. Anasis data menggunakan teknik analisi regrisi linier berganda dengan asumsi klasik normalitas auto korelasi, multikolinieritas dan heteroskedasitas. Kesimpulan dari penelitian ini berdasarkan pada uji simultan (uji f) dan uji parsial (uji t) dengan signifikasi 5\%. Berdasarkan analisis, menyimpulkan bahwa secara parsial berpengaruh tidak signifikan dan secara simultan Return On Asset, Return On Equity, Economic Value Added dan Net Profit Margin memiliki pengaruh yang signifikan 0,002 terhadap harga saham dengan koefisien determinasi $0,566 \%$. Ini menunjukan bahwa $0,566 \%$ harga saham dijelaskan oleh lima variabel independen dan selanjutnya dijelaskan oleh variabel lain yang tidak termasuk dalam penelitian ini.

Kata kunci : Return On Asset, Return On Equity, Economic Value Added,Net Profit Margin dan Harga Saham

\section{A.Pendahuluan}

Perusahaan adalah suatu badan atau organisasi yang dibangun dengan tujuan untuk mencari keuntungan melalui peningkatan kinerja keuangan untuk mempertahankan kelangsungan hidup perusahaan. Tujuan perusahaan adalah memaksimalkan laba dalam jangka panjang dengan menggunakan sumber daya secara efektif dan efisien, untuk mencapai tujuan tersebut dibutuhkan strategi perusahaan dalam mengelola manajemennya serta penilaian kinerja dengan melakukan analisis keuangan perusahaan. Profitabilitas perusahaan adalah salah satu cara untuk menilai secara tepat sejauh mana tingkat pengembalian yang akan didapat dari aktivitas investasinya. Jika kondisi perusahaan dikategorikan menguntungkan dan menjanjikan keuntungan dimasa yang akan datang maka banyak investor yang akan menanamkan dananya untuk membeli saham perusahaan tersebut. Dan hal tersebut tentu saja mendorong harga saham naik menjadi lebih tinggi. Harga saham mencerminkan juga nilai dari suatu perusahaan. Jika perusahaan mencapai prestasi yang baik, maka saham perusahaan tersebut akan banyak diminati oleh para investor.

Dalam menilai kinerja perusahaan dapat dilakukan dengan metode Return On Asset (ROA), Return On Equity (ROE) dan Economic Value Added (EVA). Karena Metode Return On Equity digunakan untuk melihat perkembangan perusahaan dan kemampuan perusahaan dalam mengembangkan modal dari pemilik dan 
investor sedangkan Economic Value Added (EVA) digunakan perusahaan sebagai pedoman dalam meningkatkan laba perusahaan dan aset yang dimiliki perusahaan tersebut dan digunakan untuk menutupi kelemahan ROA dan ROE yang terbatas pada modal dan aset saja sedangkan metode EVA sebagai analisis pembanding laba setelah pajak dengan modal yang dimiliki.

Sektor properti dan real estate merupakan sektor yang bergerak dibidang jasa. Sektor properti memperjual belikan aset properti seperti rumah atau apartemen. Sektor ini adalah sektor yang terus bertumbuh karena bisnisnya merupakan kebutuhan utama setiap orang. Namun, bukan berarti investasi pada bidang ini tidak memiliki resiko, sama dengan sektor yang lainnya, Harga saham perusahaan properti dan real estate pada tahun 2012-2016 mengalami peningkatan dari pada tahuntahun sebelumnya. Meskipun pada tahun 2012-2016 penjualan properti dan real estate sempat mengalami perlambatan, namun permintaan terhadap sektor ini tetap ada sehingga harga dari sektor ini tidak jatuh. Apabila harga saham naik, maka tingkat profitabilitasnya juga naik karena hal ini menunjukkan bahwa saham yang dari perusahaan tersebut banyak yang diminati oleh para investor. Demikian halnya jika harga saham turun sebanding dengan penurunan tingkat profitabilitas.

Pengendalian yang dilakukan oleh manajemen perusahaan dapat berupa penilaian kinerja atau prestasi seorang manajer, dengan cara menilai dan membandingkan data keuangan perusahaan selama periode berjalan. Dalam hal ini penilaian kinerja seorang manajer dapat diukur berdasarkan hasil laporan keuangan yang disajikan dalam laporan pertanggung jawabannya.

Maka dari itu akan dilakukan penelitian yang berjudul "Pengaruh Return On Asset, Return On Equity, Economic Value Added Dan Net Profit Margin Terhadap Harga Saham Di Bursa Efek Indonesia" (Studi Pada Perusahaan Real Estate \& Property) Periode 2012-2016. 
Kerangka Pemikiran

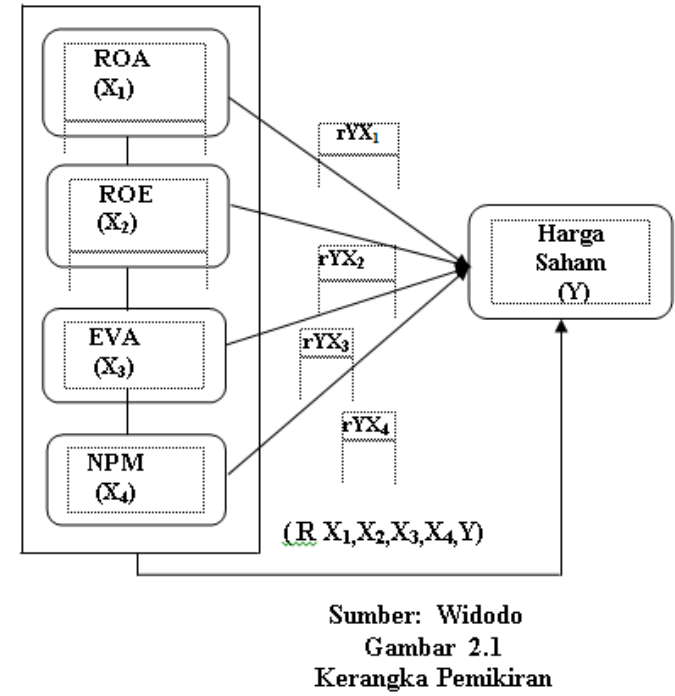

\section{B. Metode Penelitian}

Berdasarkan permasalahan yang diteliti metode yang digunakan dalam penelitian ini adalah dengan metode asosiatif dengan pendekatan kuantitatif. Menurut sugiyono (2016:11)."Metode pendekatan kuantitatif dapat diartikan sebagai metode penelitian yang berlandaskan pada filsafat positivisme, digunakan untuk meneliti pada populasi atau sample tertentu, teknik pengambilan sample pada umumnya melakukan secara random, pengumpulan data dengan instrumen penelitian, analisis data bersifat kuantitatif/ statistik dengan tujuan untuk menguji hipotesis yang telah ditetapkan".

Data kuantitatif dalam penelitian ini meliputi laporan keuangan perusahaan dalam bentuk neraca dan laporan laba rugi perusahaan perusahaan Real estate yang terdaftar di Bursa Efek Indonesia (BEI) yang di teliti dari tahun 2012-2016 yang menggambarkan ada pengaruh antara variabel yang satu dengan variabel yang lain. Dalam penelitian ini variable $\mathrm{X}_{1}$ (Return On Assets), $\mathrm{X}_{2}$ (Return On Equity), $\mathrm{X}_{3}$ Economic Value Added dan $\mathrm{X}_{4}$ Net Profit Margin dan Y (Harga saham).

\section{Populasi}

Menurut Sugiyono (2016:297) Populasi adalah wilayah generalisasi yang terdiri atas obyek atau subyek penelitian yang mempunyai kualitas dan karakteristik tertentu yang ditetapkan oleh peneliti untuk dipelajari dan kemudian ditarik kesimpulan. Populasi yang digunakan dalam penelitian ini adalah perusahaan sektor properti dan real estate yang terdaftar di BEI pada tahun 2012-2016, yaitu terdapat 51 perusahaan. Teknik Sampling yang digunakan dalam penelitian ini adalah nonrandom sampling, yaitu metode secara tidak acak dimana elemen-elemen populasi tidak mempunyai kesempatan yang sama untuk dipilih sebagai sampel serta dengan menggunakan teknik purposing sampling.

\section{Sampel}

Menurut Sugiyono (2016:297) Sample adalah bagian dari jumlah dan karakteristik yang dimiliki oleh populasi tersebut. Metode 
pengambilan sampel bertujuan digunakan apabila anggota sampel yang dipilih secara khusus berdasarkan pertimbanganpertimbangan tertentu

Dalam penelitian ini penulis melakukan perhitungan secara kuantitatif dengan menggunakan data yang berhubungan dengan Return On Equity, Return On Assets serta Harga saham dengan sampel lima tahun yang akan digunakan penulis untuk menentukan seberapa besar pengaruh Return On Equity dan Return On Assets terhadap Harga saham pada perusahaan Real estate yang terdaftar di Bursa Efek Indonesia (BEI).minimal dan nilai maksimal (Ghozali, 2011:19).

Penelitian ini mendeskripsikan variabel penelitian beserta umur pembentuknya. Variabel antara lain harga saham yang merupakan variabel terikat serta variabel bebas yaitu Return On Assets, Return On Equity, Economic Value Added dan Net Profit Margin. Dari variabel serta unsurunsur pembentuknya tersebut akan dijelaskan mengenai nilai rata-rata, nilai minimum, nilai maksimum, standar deviasi, range dan variance.

\section{Pengujian Asumsi Klasik}

\section{Uji Normalitas}

Normalitas Data merupakan hal yang penting karena dengan data yang distribusi normal, maka data tersebut dapat mewakili populasi. SPSS 22(2014:69). Uji ini untuk menguji apakah pengamatan berdistribusi secara normal atau tidak, uji ini menggunakan Kolmogorov-Smirnov. Sujarweni (2016:355)

\section{Uji Multikoloniearitas}

Uji multikolonieritas dilakukan untuk menguji apakah model regresi memiliki korelasi antar variabel bebas. Cara untuk mendeteksi adanya multikoloniearitas adalah dengan melihat nilai tolerance dan nilai Variance Inflation Factor (VIF). Kedua ukuran ini menunjukkan setiap variabel independen mana yang dijelaskan oleh variabel independen lainnya (Ghozali, 2011: 160)

\section{Uji Heteroskedasitas}

Sujarweni (2007) menjelaskan uji heterocedastisity residual perbedaan varians periode pengamatan ke periode lain pengamatan.

\section{Uji Autokorelasi}

Menguji autokorelasi dalam suatu model bertujuan untuk mengetahui ada tidaknya korelasi antara variabel pengganggu pada periode tertentu dengan variabel sebelumnya. Mendeteksi 
autokorelasi dengan menggunakan nilai Durbin Watson dengan kriteria jika:

a) Angka $\mathrm{D}-\mathrm{W}$ dibawah -2 berarti ada autokorelasi positif.

b) Angka D-W diantara -2 dan +2 berarti tidak ada autokorelasi.

c) Angka D-W diatas +2 berarti ada autokorelasi negatif.

\section{Analisis Regresi}

\section{Analisis Regresi Linier Berganda}

Analisis regresi linier berganda yaitu regresi linier yang melibatkan lebih dari dua variable, satu variable terikat (Y) dan dua atau lebih variable bebas $\left(\mathrm{X}_{1}, \mathrm{X}_{2}, \mathrm{X}_{3}, \mathrm{X}_{4} \mathrm{X}_{\mathrm{n}}\right)$.

Rumus regresi linier berganda

(Sugiyono, 2010:277)

$Y=\alpha+\beta_{1} X_{1}+\beta_{2} X_{2}+\beta_{3} X_{3}+\beta_{4} X_{4} \varepsilon$

Dimana:

$\mathrm{Y}=$ Kinerja Keuangan (Variable dependen)

$\mathrm{X}_{1}=\mathrm{ROA}$ (Variable Independen)

$\mathrm{X}_{2}=\mathrm{ROE}$ (Variable Independen)

$\mathrm{X}_{3}=\mathrm{EVA}$ (Variable Independen)

$\mathrm{X}_{4}=\mathrm{NPM}$ (Variable Independen)

$\alpha=$ Penduga bagi $\alpha$ intersep (titik potong)

$\beta_{1} \beta_{2}=$ Penduga bagi $\beta_{1} \varepsilon_{i}=$ Error

untuk mencari koefisien regresi $\alpha \beta_{1}$ dan $\quad \beta_{2} \quad$ digunakan persamaan simultan,sebagai berikut:

$$
\begin{aligned}
\sum \mathrm{X}_{1} \mathrm{Y} & =\beta_{1} \sum \mathrm{X}_{1}^{2}+\beta_{2} \sum \mathrm{X}_{1} \sum \mathrm{X}_{2} \\
\sum \mathrm{X}_{2} \mathrm{Y} & =\beta_{2} \sum \mathrm{X}_{1} \sum \mathrm{X}_{2}+\beta_{2} \sum \mathrm{X}_{2}{ }^{2} \\
\alpha \quad & =\mathrm{Y}-\beta_{1} \mathrm{X}_{1}-\beta_{2} \mathrm{X}_{2}
\end{aligned}
$$

\section{Uji Secara Parsial (Uji t)}

Uji $\mathrm{t}$ digunakan untuk mengetahui ada tidak pengaruh masing-masing variabel bebas terhadap variabel terikat.

Uji t dihitung dengan rumus :

$$
\mathrm{t}_{\mathrm{h}}=\frac{r \sqrt{n-2}}{\sqrt{1-r^{2}}}
$$

Dimana:

$\mathrm{r}=$ Koefisien Korelasi

$\mathrm{n}=$ Jumlah Sampel

$\mathrm{t}_{\mathrm{h}}=\mathrm{t}_{\text {hitung }}$

Menguji hipotesis digunakan derajat kepercayaan atau tingkat nyata n2 dan $\alpha=0,05$, jika $\mathrm{t}$ hitung $<\mathrm{t}$ table maka $\mathrm{H}_{\mathrm{o}}$ diterima dan $\mathrm{H}_{\mathrm{a}}$ ditolak sehingga tidak ada hubungan yang signifikan antara $X_{1}$ dan $\mathrm{Y}, \mathrm{X}_{2}$ dan $\mathrm{Y}, \mathrm{X}_{3}$ dan $\mathrm{Y} . \mathrm{X}_{4}$ dan $\mathrm{Y}$. Jika $t_{\text {hitung }}>\mathrm{t}_{\text {table }}$ maka $\mathrm{H}_{\mathrm{o}}$ ditolak dan $\mathrm{H}_{\mathrm{a}}$ diterima sehingga ada hubungan yang signifikan antara $\mathrm{X}_{1}$ dan $\mathrm{Y}$, dan $\mathrm{X}_{2}$ dan $\mathrm{Y}$, Sugiyono (2010:260). 


\section{Uji Signifikan Koefisien Korelasi}

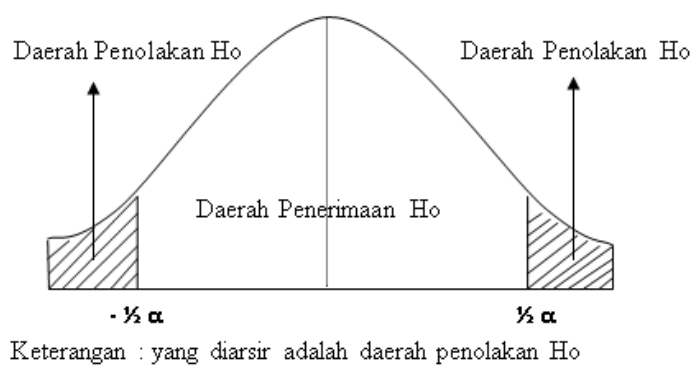

\section{Uji Secara Simultan (Uji F)}

Uji F digunakan untuk mengetahui ada tidaknya pengaruh secara bersama-sama variable bebas terhadap variable terikat (koefisien korelasi berganda).

Uji F dihitung dengan rumus:

$$
F_{h}=\frac{R^{2} / k}{\left(1-R^{2}\right) /(n . k-1)}
$$

Dimana :

$\mathrm{R}^{2}=$ Koefisien korelasi ganda yang telah ditentukan

$\mathrm{k}=$ Jumlah variable independen

$\mathrm{n}$ = Jumlah sampel data

$F_{n}=F_{\text {hitung }}$ yang selanjutnya dibandingkan dengan $F_{\text {table }}$

$\mathrm{H}_{\mathrm{o}}=$ tidak terdapat hubungan antara $\mathrm{X}_{1} \mathrm{X}_{2}$ terhadap Y

$\mathrm{H}_{\mathrm{a}}=$ ada hubungan antara $\mathrm{X}_{1} \mathrm{X}_{2}$ terhadap $\mathrm{Y}$

$\mathrm{F}_{\text {hitung }}>\mathrm{F}$ tablepada $\alpha=0,05$ maka $\mathrm{H}_{\mathrm{o}}$ ditolak dan $\mathrm{H}_{\mathrm{a}}$ diterima.

$\mathrm{F}_{\text {hitung }}<\mathrm{F}_{\text {table }}$ pada $\alpha=0,05$ maka $\mathrm{H}_{\mathrm{o}}$ diterima dan $\mathrm{H}_{\mathrm{a}}$ ditolak.
Menurut Sugioyono (2010:257).

\section{Koefisien Determinasi}

Koefisien determinasi dapat dilihat pada nilai Adjusted $R$ Square yang menunjukkan seberapa besar variable independen dapat menjelaskan variable dependen.Semakin tinggi nilai Adjusted $R$ Square maka berarti semakin baik model regresi yang digunakan karena menandakan bahwa kemampuan variable bebas menjelaskan variable terikat juga semakin besar, demikian pula apabila yang terjadi sebaliknya.

Rumus koefisien determinasi

$$
\mathrm{Kd}=r x y^{2} \times 100 \%
$$

Dimana :

$\mathrm{Kd}=$ Koefisien Determinasi

$\mathrm{Rxy}^{2}=$ Korelasi antara variable independen dan dependen.

\section{Hasil Penelitian dan Pembahasan}

Penelitian ini mengambil data dengan purposive sampling dengan Property \& Real estate periode 2012-2016. Jumlah populasi sebanyak 51 perusahaan dan Sampel yang dipilih adalah Property \& Real estate yang terdaftar di Bursa Efek Indonesia (BEI) yaitu sebanyak 25 perusahaan. Analisis data pada penelitian ini menggunakan bantuan sofware computer 
program SPSS versi 22. Analisis ini bertujuan untuk menjawab hipotesis yang dianjurkan dalam penelitian ini.

\section{Definisi Operasional Variabel}

\section{Harga Saham}

Harga saham Menurut Darmadji dan Fakhruddin (2011:102) harga saham adalah harga yang terjadi di lantai bursa pada waktu tertentu, harga saham dapat berubah naik atau turun dalam hitungan waktu yang begitu cepat, baik dalam hitungan menit maupun hitungan detik. Hal tersebut terjadi karena adanya permintaan dan penawaran saham di pasar modal.

\section{Return On Asset (ROA)}

Pada penelitian ini variable independen adalah (Return On Assets) Return On Asset (ROA) adalah rasio yang menunjukkan seberapa banyak laba bersih yang bisa diperoleh dari seluruh kekayaan yang dimiliki perusahaan.

\section{Return On Equity (ROE)}

Menurut Hery (2015:168) ROE merupakan rasio yang menunjukkan hasil (Return) atas penggunaan ekuitas perusahaan dalam menciptakan laba bersih.

\section{Economic Value Added ( EVA )}

Menurut Gendro dan Hadri (2017:77) EVA merupakan konsep yang berlandaskan pada prinsip bahwa dalam pengukuran laba perusahaan harus dengan adil mempertimbangkan harapan setiap penyandang dan (kreditor dan pemegang saham).

\section{Net Profit Margin (NPM)}

Menurut Hery (2015:235) net profit margin merupakan rasio yang digunakan untuk mengukur besarnya persentase laba bersih atas penjualan bersih. Rasio ini dihitung dengan membagi laba bersih terhadap penjualan bersih.

\section{Statistik Deskriptif}

Analisis statistik desriptif seperti tabel 1 menunjukkan nilai rata-rata (mean), minimum dan maksimum dari masingmasing variabel.

\section{Tabel 1. Hasil Statistik Deskriptif Variabel}

\begin{tabular}{|c|c|c|c|c|c|c|c|}
\hline & & & $\begin{array}{c}\text { Return } \\
\text { on assets }\end{array}$ & $\begin{array}{c}\text { Return on } \\
\text { equity }\end{array}$ & $\begin{array}{c}\text { Economic } \\
\text { value } \\
\text { added }\end{array}$ & $\begin{array}{l}\text { Net profit } \\
\text { margin }\end{array}$ & $\begin{array}{l}\text { Harga } \\
\text { saham }\end{array}$ \\
\hline \multirow[t]{2}{*}{$\mathrm{N}$} & \multicolumn{2}{|l|}{ Valid } & 25 & 25 & 25 & 25 & 25 \\
\hline & \multicolumn{2}{|c|}{ Missing } & 0 & 0 & 0 & 0 & 0 \\
\hline \multicolumn{3}{|c|}{ Mean } & 12.6170 & 7.1342 & 2.0657 & 32.4537 & 6.4900 \\
\hline \multicolumn{3}{|c|}{ Median } & 11.9780 & 6.2500 & 1.6453 & 27.9420 & 6.1438 \\
\hline \multicolumn{3}{|c|}{ Mode } & $1.49^{\mathrm{a}}$ & $1.19^{\mathrm{a}}$ & $.52^{\mathrm{a}}$ & $10.42^{\mathrm{a}}$ & $4.78^{\circ}$ \\
\hline \multicolumn{3}{|c|}{ Std. Deviation } & 6.68343 & 3.86989 & 1.08325 & 20.14185 & 1.34629 \\
\hline \multicolumn{3}{|c|}{ Variance } & 44.668 & 14.976 & 1.173 & 405.694 & 1.812 \\
\hline \multicolumn{3}{|c|}{ Range } & 25.17 & 13.63 & 3.43 & 96.81 & 4.79 \\
\hline \multicolumn{3}{|c|}{ Minimum } & 1.49 & 1.19 & .52 & 10.42 & 4.78 \\
\hline \multicolumn{3}{|c|}{ Maximum } & 26.66 & 14.81 & 3.95 & 107.23 & 9.57 \\
\hline \multicolumn{3}{|c|}{ Sum } & 315.43 & 178.36 & 51.64 & 811.34 & 162.25 \\
\hline \multirow{3}{*}{\multicolumn{2}{|c|}{ Percentiles }} & 25 & 6.9320 & 3.7920 & 1.2180 & 18.2680 & 5.3752 \\
\hline & & 50 & 11.9780 & 6.2500 & 1.6453 & 27.9420 & 6.1438 \\
\hline & & 75 & 17.0830 & 10.1140 & 3.0150 & 42.3480 & 7.2977 \\
\hline
\end{tabular}




\section{Uji Normalitas}

Uji ini untuk menguji apakah pengamatan berdistribusi secara normal atau tidak, uji ini menggunakan OneSample Kolmogorov-Smirnov. Hasil uji normalitas dapat dilihat pada tabel berikut ini:

Tabel 2.

Uji Normalitas Kolmogorov-Smirnov.

One-Sample Kolmogorov-Smirnov Test

\begin{tabular}{|c|c|c|c|c|c|}
\hline & ROA & ROE & EVA & NPM & $\begin{array}{c}\text { Harg } \\
\text { a } \\
\text { saha } \\
\text { m }\end{array}$ \\
\hline $\mathrm{N}$ & 25 & 25 & 25 & 25 & 25 \\
\hline Norm Mean & 12.617 & 7.134 & 2.065 & 32.453 & 6.49 \\
\hline & & 2 & 7 & 7 & 00 \\
\hline $\begin{array}{ll}\text { Para } & \text { Std. } \\
\text { meter } & \text { Deviat }\end{array}$ & 6.6834 & 3.869 & 1.083 & 20.141 & 1.34 \\
\hline $\mathrm{s}^{\mathrm{a}, \mathrm{b}}$ ion & & 89 & 25 & 85 & 629 \\
\hline $\begin{array}{ll}\text { Most Absol } \\
\text { Extre ute }\end{array}$ & .072 & .122 & . 174 & . 142 & . 162 \\
\hline $\begin{array}{ll}\text { me } & \text { Positiv } \\
\text { Diffe } & \mathrm{e}\end{array}$ & .072 & .122 & .174 & .142 & .162 \\
\hline $\begin{array}{ll}\text { rence } & \text { Negati } \\
\mathrm{S} & \text { ve }\end{array}$ & -.063 & -.062 & -.116 & -.137 & -.102 \\
\hline Test Statistic & .072 & .122 & .174 & .142 & .162 \\
\hline $\begin{array}{l}\text { Asymp. Sig. } \\
\text { (2-tailed) }\end{array}$ & $200^{\mathrm{c}, \mathrm{d}}$ & $.200^{\mathrm{c}}$ & $.050^{\mathrm{c}}$ & $.200^{\mathrm{c}, \mathrm{d}}$ & $.088^{\mathrm{c}}$ \\
\hline
\end{tabular}

Sumber: Data sekunder, diolah SPSS 22, 2018

Tabel 3.

Hasil Uji Multikolinieritas

Coefficients $^{\mathrm{a}}$

\begin{tabular}{|c|c|c|c|c|c|c|c|}
\hline & \multicolumn{2}{|c|}{$\begin{array}{c}\text { Unstandar } \\
\text { dized } \\
\text { Coefficie } \\
\text { nts } \\
\end{array}$} & $\begin{array}{c}\text { Stand } \\
\text { ardize } \\
\mathrm{d} \\
\text { Coeff } \\
\text { icient } \\
\mathrm{s} \\
\end{array}$ & & & \multicolumn{2}{|c|}{$\begin{array}{c}\text { Collinearity } \\
\text { Statistics }\end{array}$} \\
\hline & $\mathrm{B}$ & $\begin{array}{c}\text { Std. } \\
\text { Erro } \\
r\end{array}$ & Beta & $\mathrm{t}$ & $\begin{array}{l}\mathrm{Si} \\
\text { g. }\end{array}$ & $\begin{array}{c}\text { Toleran } \\
\text { ce }\end{array}$ & VIF \\
\hline
\end{tabular}

\begin{tabular}{|c|c|c|c|c|c|c|c|}
\hline $\begin{array}{l}1 \text { (Const } \\
\text { ant) }\end{array}$ & $\begin{array}{r}4.4 \\
04\end{array}$ & .662 & & $\begin{array}{r}6.6 \\
52\end{array}$ & $\begin{array}{r}.00 \\
0\end{array}$ & & \\
\hline ROA & $\begin{array}{r}.04 \\
1\end{array}$ & .069 & 204 & $\begin{array}{r}.59 \\
6\end{array}$ & $\begin{array}{r}.55 \\
8\end{array}$ & .185 & 5.411 \\
\hline ROE & $\begin{array}{r}.26 \\
5\end{array}$ & 149 & .762 & $\begin{array}{r}1.7 \\
81\end{array}$ & $\begin{array}{r}.09 \\
0\end{array}$ & .119 & 8.438 \\
\hline EVA & $\begin{array}{r}.22 \\
5\end{array}$ & 192 & 181 & $\begin{array}{l}1.1 \\
72\end{array}$ & $\begin{array}{r}.25 \\
5\end{array}$ & .911 & 1.098 \\
\hline NPM & $\begin{array}{r}.02 \\
4\end{array}$ & .016 & -.364 & $\begin{array}{r}-5 \\
1.5 \\
47\end{array}$ & $\begin{array}{r}.13 \\
8\end{array}$ & .392 & 2.551 \\
\hline
\end{tabular}

a. Dependent Variable: Harga saham

Sumber: Data sekunder, diolah SPSS 22, 2018

Dari hasil pengolahan data menunjukkan bahwa variabel bebas tidak memiliki nilai VIF yang melebihi 10, sehingga dapat disimpulkan bahwa tidak terjadi Multikolinieritas.

Gambar 1.

Hasil Heteroskedasitas

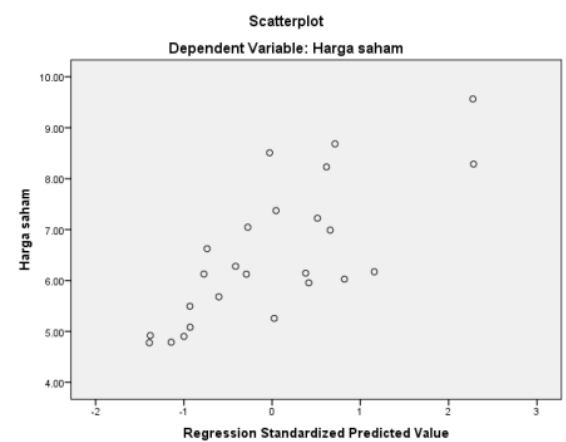

Sumber: Data sekunder, diolah SPSS 22, 2018

Dari hasil pengolahan data pada gambar terlihat bahwa pola penyebaran berada diatas dan dibawah sumbu $\mathrm{Y}$ dan tidak membentuk pola tertentu, maka dapat disimpulkan bahwa model ini tidak terjadi gangguan Heteroskedasitas. 
Tabel 4.

Hasil uji Autokorelasi

Model Summary

\begin{tabular}{|l|l|r|r|r|r|}
\hline $\begin{array}{l}\text { Mo } \\
\text { del }\end{array}$ & $\mathrm{R}$ & $\begin{array}{c}\mathrm{R} \\
\text { Square }\end{array}$ & $\begin{array}{c}\text { Adjusted } \\
\text { R Square }\end{array}$ & $\begin{array}{c}\text { Std. Error } \\
\text { of the } \\
\text { Estimate }\end{array}$ & $\begin{array}{c}\text { Durbin- } \\
\text { Watson }\end{array}$ \\
\hline 1 & $.752^{\mathrm{a}}$ & .566 & .479 & .97157 & 2.329 \\
\hline
\end{tabular}

Sumber: Data sekunder, diolah SPSS 22, 2018

Dari hasil output dapat disimpulkan bahwa nilai ROA,ROE,EVA dan NPM Durbin-Watson adalah 2.329 atau berada +2 maka dapat dipastikan bahwa model tersebut mengalami autokorelasi negatif. +2 maka dapat dipastikan bahwa model tersebut mengalami autokorelasi negatif.

Tabel 5.

Hasil Uji Regresi Linier Berganda

\section{Coefficients $^{\mathrm{a}}$}

\begin{tabular}{|l|r|r|r|r|r|}
\hline \multirow{2}{*}{ Model } & \multicolumn{2}{|c|}{$\begin{array}{c}\text { Unstandardized } \\
\text { Coefficients }\end{array}$} & $\begin{array}{c}\text { Standardized } \\
\text { Coefficients }\end{array}$ & & \\
\cline { 2 - 5 } & \multicolumn{1}{c|}{$\mathrm{B}$} & Std. Error & \multicolumn{1}{c|}{ Beta } & \multicolumn{1}{c|}{$\mathrm{t}$} & \multicolumn{1}{c|}{ Sig. } \\
\hline 1 (Constant) & 4.404 & .662 & & 6.652 & .000 \\
$\begin{array}{l}\text { Retum on } \\
\text { assets }\end{array}$ & .041 & .069 & .204 & .596 & .558 \\
$\begin{array}{l}\text { Retum on } \\
\text { equity }\end{array}$ & .265 & .149 & .762 & 1.781 & .090 \\
$\begin{array}{l}\text { Economic } \\
\text { value } \\
\text { added }\end{array}$ & .225 & .192 & .181 & 1.172 & .255 \\
$\begin{array}{l}\text { Net profit } \\
\text { margin }\end{array}$ & -.024 & .016 & -364 & 1.547 & .138 \\
\hline
\end{tabular}

Sumber: Data sekunder, diolah SPSS 22, 2018

1. Hasil uji - t test $\mathrm{H} 1$ diperoleh angka 0.596 dengan nilai signifikansi sebesar 0,558. Karena tingkat signifikansi $>\alpha=$ 0,05, maka ROA (X1) berpengaruh terhadap Harga Saham (Y) secara parsial.
2. Hasil uji $-\mathrm{t}$ test $\mathrm{H} 2$ diperoleh angka 1.781dengan nilai signifikansi sebesar 0.090. Karena tingkat signifikansi $<\alpha=$ 0,05, maka ROE (X2) berpengaruh terhadap Harga Saham (Y) secara parsial. Hasil uji - $t$ test $\mathrm{H} 3$ diperoleh angka 1.172 dengan nilai signifikansi sebesar 0,225 . Karena tingkat signifikansi $<\alpha=$ 0,05, maka EVA (X3) tidak berpengaruh terhadap Harga Saham (Y) secara parsial.

4. Hasil uji $-\mathrm{t}$ test $\mathrm{H} 4$ diperoleh angka 2.706 dengan nilai signifikansi sebesar 0,014. Karena tingkat signifikansi $>\alpha=$ 0,05, maka NPM (X4) berpengaruh terhadap Harga Saham (Y) secara parsial.

Tabel 6.

Hasil Uji F

ANOVA $^{\mathrm{a}}$

\begin{tabular}{|c|c|c|c|c|c|}
\hline Model & $\begin{array}{l}\text { Sum of } \\
\text { Squares }\end{array}$ & df & $\begin{array}{l}\text { Mean } \\
\text { Square }\end{array}$ & $\mathrm{F}$ & Sig. \\
\hline 1 Regression & 24.621 & 4 & \multirow{3}{*}{$\begin{array}{r}6.155 \\
.944\end{array}$} & \multirow[t]{3}{*}{6.521} & \multirow[t]{3}{*}{$.002^{b}$} \\
\hline Residual & 18.879 & 20 & & & \\
\hline Total & 43.500 & 24 & & & \\
\hline
\end{tabular}

Sumber: Data sekunder, diolah SPSS 22, 2018

\section{Kriteria :}

Jika F hitung > F tabel, maka Ho ditolak dan Ha diterima.

Jika $\mathrm{F}$ hitung $<\mathrm{F}$ tabel, maka Ho diterima dan Ha ditolak.

Atau

Jika $\mathrm{P}<0,05$, maka Ho ditolak dan Ha diterima. 
Jika $\mathrm{P}>0,05$, maka Ho diterima dan $\mathrm{Ha}$ ditolak.

Dengan tingkat signifikan 5\% dan derajat kebebasan df1 $=4$ dan df $2=20$ maka tabel didapat $\mathrm{F}(4 ; 20)=2,866$. Dalam perhitungan diperoleh nilai $\mathrm{F}$ hitung lebih besar dari $\mathrm{F}$ tabel, yaitu 6,521 > 2,866 sehingga Ho ditolak.

\section{Koefisien Determinasi (R2)}

Hasil pengolahan data uji Koefisien korelasi dan koefisien determinasi sebagai berikut:

Tabel 7.

Hasil Uji Koefisien Determinasi (R2)

Model Summary ${ }^{b}$

\begin{tabular}{|l|c|r|c|c|}
\hline Model & $\mathrm{R}$ & $\begin{array}{c}\mathrm{R} \\
\text { Square }\end{array}$ & $\begin{array}{c}\text { Adjust } \\
\text { ed R } \\
\text { Squar } \\
\mathrm{e}\end{array}$ & $\begin{array}{c}\text { Std. Error of the } \\
\text { Estimate }\end{array}$ \\
\hline 1 & $.752^{\mathrm{a}}$ & .566 & .479 & .97157 \\
\hline
\end{tabular}

Sumber: Data sekunder, diolah SPSS 22, 2018

Hasil koefisien determinasi adjusted

R Squere sebesar 0, 566 yang menunjukkan bahwa $56,6 \%$ harga saham di pengaruhi oleh variabel Return on assets, return on equity, economic value added, net profit margin, sisanya $43,4 \%$ harga saham perusahaan Property \& Real estate yang terdaftar di Bursa Efek Indonesia (BEI) periode 20122016 dipengaruhi oleh variabel lain yang diluar model regresi.

\section{Simpulan}

Berdasarkan hasil dan pembahasan yang telah diuraikan, maka dapat ditarik kesimpulan sebagai berikut:

1. Variabel ROA (X1) berpengaruh signifikan terhadap harga saham perusahaan Property \& Real estate yang terdaftar di Bursa Efek Indonesia tahun 2012-2016.

2. Variabel ROE (X2) berpengaruh signifikan terhadap harga saham perusahaan Property \& Real estate yang terdaftar di Bursa Efek Indonesia tahun 2012-2016.

3. Variabel EVA (X3) berpengaruh signifikan terhadap harga saham perusahaan Property \& Real estate yang terdaftar di Bursa Efek Indonesia tahun 2012-2016.

4. Variabel NPM (X4) berpengaruh signifikan terhadap harga saham perusahaan Property \& Real estate yang terdaftar di Bursa Efek Indonesia tahun 2012-2016.

5. Variabel ROA, ROE, EVA dan NPM secara simultan berpengaruh signifikan terhadap harga saham perusahaan Property \& Real estate yang terdaftar di Bursa Efek Indonesia tahun 2012-2016. 


\section{E. Daftar Pustaka}

Amin Widjaja Tunggal (2008). Pengantar Konsep Nilai Tambah Ekonomi (EVA) dan Value Based Management (VBM). Harvarindo.

Anggraeni, C.M. 2017.Pengaruh Profitabilitas Dan Market Value Added Terhadap Harga Saham Pada Perusahaan Manufaktur. (diunduh 21februari 2018).

Brigham, F dan Houston J.F.2010.DasarDasar Manajemen Keuangan.Singapore: Salemba Empat.

Dita, N. C. 2017.Pengaruh economic value added (EVA), net profit margin (NPM), return on equity (ROE), dan return on investment (ROI) terhadap harga saham. (studi pada perusahaan jasa sektor utilitas, infrastruktur dan transportasi yang terdaftar di BEI tahun 2013-2015. (diunduh 21februari 2018).

Fadilah, Zaidatul.2017.pengaruh economic value added (EVA), net profit margin (NPM) return on asset (ROA), return on equity (ROE), earning per share (EPS) Dan Price Earning Ratio (Per) Terhadap Harga Saham. (journal online). (diunduh 21februari 2018).

Fahmi, Irham.2014.Analisis Kinerja Keuangan.Bandung:Alfabeta.

http://journal.unnes.ac.id/sju/index.php/aaj. (diunduh 21februari 2018). http://suryanieti.blogspot.co.id/2012/06/desa in-penelitian-kuantitatif.html. (diunduh 12 Maret 2018).

https://en.wikipedia.org/wiki/Economic_val ue_added.).(diunduh 18 februari 2018).

Husnan,

Suad.2015.Dasar-Dasar Manajemen Keuangan.Yogyakarta: UPP STIM YKPN.

Ikatan akuntansi indonesia.2012. standar akuntansi keuangan.jakarta:salemba empat.

Kadar, Kusnadi, Rikumahu, Brady.(2017). Relationship Analysis Between EVA, EPS, ROA, ROE To MVA For Measuring Financial Performance (Case Study On Telecommunication Companies Listed In Idx 20112016). .(journal online). (diunduh 22 februari 2018).

Kamatra, Novrianty, Kartikaningdyah, Ely. 2015. Effect Corporate Social Responsibility on Financial Performance. International Journal of Economics and Financial Issues. .journal online).ISSN: 2146-4138.(diunduh 20 februari 2018).

Kasmir.2015.Analisis Laporan Keuangan.Jakarta:Rajawali.

Monisa Wati, Like. 2012. Pengaruh Praktek Good Corporate Governance Terhadap Kinerja Keuangan Perusahaan Di Bursa Efek Indonesia Good Corporate Governance (GCG), Return on Equity (ROE), Net Profit Margin (NPM). .(journal online).(diunduh 21februari 2018). 
Munawir,2016. Analisa Laporan Keuangan.Yogyakarta:Liberty

Novita, dina . 2013. Analisis economic value added (EVA) dan return on aseets (ROA)) sebagai alat ukur penilaian kinerja keuangan. ( studi kasus pada PT. Jaya Real Property). (journal online). (diunduh 21 februari 2018).

Novita, Dina. 2005. Analisis economic value added (EVA) dan return on assets (ROA) sebagai alat ukur penilaian kinerja keuangan. (Studi kasus pada PT. Jaya real property). (diunduh 21februari 2018).

Prasinta , Dian. 2012. Pengaruh Good Corporate Governance Terhadap Kinerja Keuangan.(jurnal online) Accounting Analysis Journal

Priyatri, Duwi. 2014. SPSS 22 Pengolahan data praktis - edisi kesatu.

Yogyakarta : ANDI. (diunduh 21februari 2018).

Rahayu, A. M. 2014. Analisis pengaruh rasio profitabilitas dan economic value Added terhadap harga sahampada sub sektor industri semen yang terdaftar di bursa efek Indonesia. (diunduh 21februari 2018).

Riyanto,Bambang.2010.Dasar-Dasar Pembelanjaan Perusahaan. Yogyakarta:BPFG.
Santy, V. A. D. 2017. Pengaruh ROA, dan EPS terhadap harga saham PT. Garuda Indonesia Tbk. (diunduh 21februari 2018).

Suciyati, Tri. 2010. Pengaruh ROA, ROE, NPM, EPS dan EVA Terhadap Harga Saham Sektor Pertambangan yang Terdaftar Di $B E I$. (diunduh 21februari 2018). (diunduh 21februari 2018).

Sugiyono.2016. Metode Penelitian Kombinasi Mixed Methods. Bandung: ALFABETA

$\begin{array}{ccr}\text { Sujarweni,Wiratna } & \text { V.2016. } & \text { Penelitian } \\ \text { akuntansi } & \text { dengan } & \text { SPSS. } \\ \text { Yogyakarta:Pustaka Baru Press. }\end{array}$

Van Horne, James C..2008.Fundamentals of financial Management. England: Ashford Colour Press Ltd., Gosport

Wiyono,Gendro dan Kusuma H.2017.Manajemen Keuangan Lanjutan Berbasis Corporate Value Creation. Yogyakarta: UPP STIM YKPN.

Www.idx.co.id 